\title{
Quality of life based on level of physical activity among elderly residents of urban and rural areas
}

Cezar Grontowski Ribeiro'

Fátima Ferretti ${ }^{2}$

Clodoaldo Antônio de Sá2

\section{Abstract}

Objective: To analyze quality of life (QOL) according to level of physical activity among elderly persons living in rural (RA) and urban (UA) areas. Method: A descriptive crosssectional study, analyzing 358 elderly residents of RA and 139 of UA, in the municipal region of Palmas, Paraná, Brazil was performed. Quality of life, level of physical activity and economic condition were evaluated. For the analysis of the continuous variables, the student's t-test or the Mann-Whitney test were used, based on the normality or otherwise of the data. Pearson's chi-squared or Fischer's exact test were used to analyze the categorical variables. Results: The general perception of QOL reported in RA was better than in UA $(p<0.05)$. The analysis of the level of physical activity according to place of residence showed that the elderly are more physically active in RA $(p<0.05)$, whereas insufficiently active or sedentary subjects prevail in UA. The variables age and gender were not associated with QOL ( $p>0.05)$, irrespective of place of residence, and active elderly persons had better QOL scores than insufficiently active or sedentary individuals, again irrespective of place of residence $(p<0.05)$. Conclusion: The present study provides evidence that QOL is positively influenced by both maintaining satisfactory levels of physical activity and by residing in RA. It is important to establish public policies aimed at ensuring a more active and independent old age, thus generating greater health and quality of life.

\footnotetext{
1 Instituto Federal do Paraná, Curso de Educação Física. Palmas, PR, Brasil.

2 Universidade Comunitária da Região de Chapecó, Programa de Pós-Graduação em Ciências da Saúde. Chapecó, SC, Brasil.
}

Keywords: Health of the elderly. Aging. Quality of Life. Motor Activity. 


\section{INTRODUCTION}

Quality of life (QoL) is understood by the World Health Organization ${ }^{1}$ from a multidimensional perspective associated with objective and subjective factors, based on criteria of individual satisfaction and collective well-being, reflecting the perception of individuals with what is described as their level of satisfaction with their basic needs, economic development, social integration, the quality of the environment in which they live, their opportunities in life and access to services, as well as issues referring to happiness, love, satisfaction with life and personal fulfillment ${ }^{2-4}$.

The elderly population in Brazil has undergone rapid growth, and in the coming years the country will have the sixth largest population of people aged over 60 in the world ${ }^{5}$. One result of this phenomenon has been an increase in the number of elderly people in urban areas in comparison with other age groups, with a decrease in the elderly population in rural areas $^{6}$. According to an IBGE report, this greater urban concentration has the following causes: the process of industrialization, better living conditions and access to services, especially health care, and the movement of the elderly to urban centers because of relatives who are established in the cities ${ }^{7}$. In view of the new challenges imposed by this reality, it is necessary to find strategies that ensure that this phase of life is lived with independence, autonomy and quality of life, in which the regular practice of physical activity (PA) can play an important role.

Physical activity has been described as fundamental to health and QoL gains in various phases of life, especially after the age of 60 , when the level of PA decreases with age, with possible deleterious effects on the QoL of the elderly ${ }^{8,9}$.

Living in rural areas (RA) and urban areas (UA) presents differences that can directly impact the life of the elderly. In RA, physical activities can differ both in relation to the level of work and the type of activity performed. There are more occupational activities, predominantly agricultural labor (family farming, extensive or subsistence), domestic activities, livestock, vegetable extractivism, and beekeeping, among others. Activity in UA is more focused on the development of technology and information, where the elderly tend to group together in centers of coexistence and reduce their work and domestic activities. These factors, associated with other aspects such as socioeconomic and educational inequalities, can influence the practice of physical activity and QoL differently in rural and urban populations ${ }^{10-13}$.

Studies about the living conditions of the elderly in the rural or urban environment are extremely important, and can subsidize actions and policies aimed at promoting the quality of life of these populations ${ }^{14}$. The present study therefore aimed to analyze quality of life based on the level of physical activity of elderly persons living in urban and rural areas in the municipal region of Palmas, in the state of Paraná, Brazil.

\section{METHOD}

A quantitative, cross-sectional descriptive study was performed of elderly residents of the municipal region of Palmas, located in the southwest region of the state of Paraná, Brazil.

A minimum sample size was calculated considering an elderly population of the municipal region of 3,236 subjects (finite population), with a sample error of $5 \%$ and a confidence level of $95 \%$. Subjects who did not reach a minimum score in the Mini Mental State Exam (MMSE), have the required educational level ${ }^{15}$, or who were not located at home on two attempts were excluded from the study. In these cases, a new subject was randomly selected until the desired number was reached.

The individual registration numbers of the elderly persons provided by the Health Department of the municipal region of Palmas were used to select the sample. All the elderly individuals were randomly selected based on their registration number using a random number table. The subjects selected represented 15 urban districts and 13 rural localities or settlements from the urban region and were interviewed in their homes.

Each individual selected to form part of the sample was contacted in advance and the objectives and procedures of the study were explained. Once the elderly person agreed to participate, the day and time when he or she would receive a visit from an evaluator at home was scheduled. On the day of the 
interview, each subject was again informed about the study procedures and signed a Free and Informed Consent Form immediately before responding to the survey instruments. The research project was approved by the Ethics Committee on Research involving human beings of UNOCHAPECÓ/SC (Approval n 048/13).

Initially, an assessment of cognitive status was performed with the Mini Mental State Exam $(\mathrm{MMSE})^{15}$. A quality of life assessment was then carried out using two instruments: the Whoqol-Bref Quality of Life Questionnaire - reduced Portuguese version $^{16}$ and the Quality of Life Assessment Questionnaire adapted for the elderly, Whoqol-Old, Portuguese version ${ }^{17}$.

The level of the practice of physical activity and economic condition were then evaluated. For these, the International Physical Activity Questionnaire Short Version (IPAQ) ${ }^{18}$ and the ABEP ${ }^{19}$ economic classification questionnaire, respectively, were used. For analysis of the level of the practice of physical activity, two categories were defined: a) Insufficiently Active or Sedentary (IAS): elderly persons who reported not practicing any physical activity, or less than 150 minutes of physical activity per week; b) Active (A): those who reported more than 150 minutes of weekly physical activity. For the evaluation of economic condition, which estimates the purchasing power of individuals and families and divides them into economic classes, the elderly were placed in two categories: upper mean income (UMI) which included subjects from classes A and $\mathrm{B}$ and lower mean income (LMI) for those in classes $\mathrm{C}, \mathrm{D}$ and $\mathrm{E}$.

Prior to the beginning of data collection, 25 evaluators were trained to use the instruments mentioned above, and then participated in a pilot study in which 20 elderly people from the Instituto Federal do Paraná (IFPR) (Paraná Federal Institute) (IFPR) swimming program, Palmas Campus, were evaluated. Data collection occurred from June to August 2013. When inconsistent data were found, they were verified in the data collection sheet and corrected.

For analysis, data were presented as mean and standard deviation (for continuous variables) or frequency and percentage (categorical variables).
The normality of continuous data was verified using the Kolmogorov-Smirnov test. Analysis of the association between level of physical activity and place of residence was performed using the Pearson Chi-squared test. The Mann-Whitney test was used for comparisons of the QoL domains assessed by the Whoqol-Bref and Whoqol-Old according to place of residence. In order to analyze the general perception of quality of life (assessed by the two instruments) according to level of physical activity and place of residence, the subjects were classified as: insufficiently active or sedentary in the rural area, active in the rural area, insufficiently active or sedentary in the urban area and active in the urban area. The comparisons between these categories were performed using the Kruskal-Wallis test and when statistically significant differences were found, the variables relating to the general perception of QoL were classified (ranked) and the Least Significant Difference (LSD) test for multiple comparisons was applied. The alpha or significance level was determined a priori as $p \leq 0.05$.

\section{RESULTS}

The sample of the present study consisted of 497 elderly persons; 358 residents of urban areas (age $70.51 \pm 7.21$ years) and 139 residents of rural communities and settlements (age 69.15 \pm 7.91 years), with $57 \%$ of the total sample being female (Table 1).

An evaluation of quality of life using the WhoqolBref based on place of residence (Table 2) showed that subjects living in the rural area had a more positive perception of quality of life in relation to the psychological domain, social relationships and the environment $(p<0.000)$. However, the scores of the elderly for the physical domain and the overall mean of the instrument did not differ significantly ( $p>0.05)$ based on place of residence.

When the Whoqol-Old instrument was used to evaluate QoL, both overall quality of life and quality of life assessed through the Autonomy, Past, Present and Future Activities, Social Participation, Death and Dying, and Intimacy domains were perceived more positively by elderly residents in rural areas $(p<0.001)$. The perception of quality of life assessed through the sensory abilities domain was more positive for elderly persons living in the urban environment $(p>0.05)$. 
The overall perception of QoL scores of the elderly assessed by the Whoqol-Bref did not differ significantly between the groups $(p>0.05)$, whereas in overall analysis by Whoqol-Old, the rural elderly presented significantly greater values $(p<0.000)$ than the elderly living in urban areas (Table 2).
Table 3 shows that level of physical activity was significantly associated with place of residence $(p<0.000)$, with the data revealing that active elderly persons predominated in the rural environment (66.91\%), while $51.7 \%$ of individuals in urban areas were insufficiently active or sedentary.

Table 1. Characterization of subjects of sample based on gender, income and place of residence. Palmas, Paraná, 2014.

\begin{tabular}{lllll}
\hline & \multicolumn{3}{c}{ Urban areas } & \multicolumn{2}{c}{ Rural areas } \\
& Upper Mean Income & Lower Mean Income & Upper Mean Income & Lower Mean Income \\
& $\mathrm{N}(\%)$ & $\mathrm{N}(\%)$ & $\mathrm{N}(\%)$ & $\mathrm{N}(\%)$ \\
\hline Male & $21(15.1)$ & $118(84.9)$ & $1(1.4)$ & $72(98.6)$ \\
\hline Female & $37(16.9)$ & $182(83.1)$ & $0(0.0)$ & $66(100.0)$ \\
\hline Total & $58(16.2)$ & $300(83.8)$ & $1(0.7)$ & $138(99.3)$ \\
\hline
\end{tabular}

Table 2. Comparison of mean quality of life scores of elderly residents in rural and urban areas. Palmas, Paraná, 2014.

\begin{tabular}{lllll}
\hline Perception of QoL & Quality of life domains & Rural areas & Urban areas & $\mathrm{p}^{*}$ \\
\hline Whoqol-Bref & Physical & $3.33( \pm 0.74)$ & $3.31( \pm 0.65)$ & 0.892 \\
& Psychological & $3.82( \pm 0.49)$ & $3.51( \pm 0.55)$ & 0.000 \\
& Social Relations & $3.88( \pm 0.57)$ & $3.60( \pm 0.63)$ & 0.000 \\
& Environment & $3.37( \pm 0.48)$ & $3.10( \pm 0.62)$ & 0.000 \\
\cline { 2 - 5 } Whoqol-Old & Overall mean of instrument & $3.53( \pm 0.75)$ & $3.54( \pm 0.72)$ & 0.983 \\
& Sensory Abilities & $3.08( \pm 0.50)$ & $3.27( \pm 0.41)$ & 0.000 \\
& Autonomy & $3.78( \pm 0.56)$ & $3.33( \pm 0.76)$ & 0.000 \\
& Past. Present and Future Activities & $3.72( \pm 0.57)$ & $3.46( \pm 0.67)$ & 0.000 \\
& Social Participation & $3.64( \pm 0.60)$ & $3.31( \pm 0.64)$ & 0.000 \\
& Death and Dying & $4.35( \pm 0.89)$ & $3.89( \pm 0.93)$ & 0.000 \\
& Intimacy & $3.88( \pm 0.68)$ & $3.47( \pm 0.85)$ & 0.000 \\
\cline { 2 - 4 } & Overall mean of instrument & $3.74( \pm 0.35)$ & $3.46( \pm 0.50)$ & 0.000 \\
\hline
\end{tabular}

Mann Whitney Test $\left({ }^{*} p<0.05\right)$

Table 3. Percentage distribution of subjects of sample based on place of residence (rural and urban areas) by level of physical activity. Palmas, Paraná, 2014.

\begin{tabular}{lll}
\hline & Rural areas* & Urban areas \\
& $\mathrm{N}(\%)$ & $\mathrm{N}(\%)$ \\
\hline Active & $93(66.9)$ & $173(48.3)$ \\
\hline Insufficiently active or sedentary & $46(33.1)$ & $185(51.7)$ \\
\hline Total & $139(100)$ & $358(100)$ \\
\hline
\end{tabular}

Chi-squared test $\left({ }^{*} p<0.000\right)$. 
Analysis of quality of life according to place of residence and level of physical activity (Table 4) found that physically active elderly persons in the urban environment had significantly higher overall quality of life scores than the insufficiently active or sedentary elderly ( $\mathrm{p}<0.05)$, regardless of the instrument used. In contrast, the general perception of quality of life in rural areas was not significantly statistically different between the active and insufficiently active elderly groups for either instrument used ( $p>0.05)$.
The analysis of quality of life with the WhoqolBref (Table 4) did not reveal significant differences in the overall perception of quality of life among active rural and urban elderly persons, or between insufficiently active or sedentary persons from the two environments ( $p>0.05)$. However, when the Whoqol-Old was used, active and insufficiently active or sedentary elderly people in rural areas had a significantly higher overall perception of quality of life than their respective urban counterparts $(p<0.05)$.

Table 4. Comparison between overall levels of perception of quality of life among rural and urban elderly persons in the municipal region and place of residence. Palmas, Paraná, 2014.

\begin{tabular}{|c|c|c|c|c|c|c|}
\hline & \multicolumn{2}{|l|}{ Whoqol-Bref } & \multirow[t]{2}{*}{$p$} & \multicolumn{2}{|l|}{ Whoqol-Old } & \multirow[t]{2}{*}{$p$} \\
\hline & Active & IAS & & Active & IAS & \\
\hline Rural areas & $3.60( \pm 0.75)$ & $3.39( \pm 0.74)$ & $.274^{*}$ & $3.77( \pm 0.43)$ & $3.70( \pm 0.25)$ & $0.360 *$ \\
\hline Urban areas & $3.69( \pm 0.64)$ & $3.40( \pm 0.76)$ & $.000 *$ & $3.67( \pm 0.44)$ & $3.30( \pm 0.61)$ & $0.000^{*}$ \\
\hline$P$ & $0.330^{*}$ & $0.762^{*}$ & & $0.002 *$ & $0.000^{*}$ & \\
\hline
\end{tabular}

IAS = Insufficiently active or sedentary; The test used for comparisons was Kruskal-Wallis ( $p<0.05)$; *Post-hoc LSD for multiple comparisons between categories: sedentary or insufficiently active from rural areas, active from rural areas, sedentary or insufficiently active from urban areas and active from urban areas.

\section{DISCUSSION}

One of the main findings of the present study was the fact that the elderly from RA reported a better general perception of quality of life than their peers in the urban zone. In the comparison, it was observed that the RA elderly scored higher in the psychological, social relations and relations with the environment domains of the Whoqol-Bref, and also in aspects such as autonomy, past, present and future activities, social participation, death and dying, intimacy, and overall Whoqol-Old score, than the elderly from UA, or in other words, in the perception of practically all the analyzed questions.

This finding can be explained in large part by the fact that in the municipality of Palmas, Paraná, rural communities are mainly based on family agriculture and timber extraction. In such cases, it is understood that the social structure and arrangements of this environment offer greater social and familial conviviality, more active participation in the community, elevated autonomy and improved performance of daily physical activities, in which the productive life of the elderly persists for longer. Even after retirement, elderly persons continue to perform work, remaining productive and active, which may have contributed to the more positive perceptions of QoL of this group ${ }^{20}$.

A study on the environmental and health conditions of urban and rural elderly persons in the northeast of Brazil found that the average income of the elderly in both rural and urban areas is one minimum wage. However, for the urban elderly, this represents the main source of income and, in many cases, financial support for their family, while for the rural elderly it is a complement to the other benefits of work, which are mainly related to agricultural activities $^{21}$.

A study carried out in Portugal on the psychosocial conditions of the elderly concluded that place of residence plays a fundamental role in the concept of quality of life of the elderly, as the rural environment instills less pressure on the elderly, 
due to the closeness of the family context and greater activity, whereas greater inactivity and isolation of the elderly was observed in urban environments ${ }^{22}$. Similarly, results have been found that show that urban elderly persons are more prone to develop depression due to loneliness, and which identify a better quality of life in the rural environment, which may have occurred with the group studied in the present work ${ }^{23}$.

Research into the organization of rural settlements and citizenship stresses that the family agriculture model is based on collective work, with the elderly participating more in the carrying out of daily activities, maintaining a social role in the community where they reside ${ }^{24}$.

The highest score in the Whoqol-Bref was in the social relations domain, both in RA and RU, a finding which occurred in other surveys of the elderly ${ }^{3,25}$. These studies attribute this result to the good network of support and social relations of elderly persons, especially in the rural environment. In a study of elderly people of both genders, rural individuals presented better results than their urban counterparts in all the domains of the Whoqol-Bref (overall and in the physical, psychological, social and environmental domains) ${ }^{23}$.

The results of a comparative study between rural and urban elderly persons that surveyed both QoL and social support found more positive levels of both physical functioning and social support among rural individuals ${ }^{26}$. It has also been shown that social networks in urban environments are smaller than in rural areas and that the most significant aspects were frequent contact with relatives, identity with environment and the feeling of belonging to a social group, factors that may also be attributed to the results of the present study, as the rural elderly live mostly in settlements or communities, in direct and daily contact with their relatives ${ }^{21,23,27}$.

In addition to the described conditions, it is believed that greater access to public health and social policies and improved hygiene, transportation and communication conditions, among other factors, have diminished the differences between these regions and, consequently, a better perception of QoL, especially in rural areas ${ }^{25}$.
In the Whoqol-Old, the facet that presented the highest score in both the rural and urban territories was death and dying, an outcome also identified in another study with the elderly ${ }^{28}$. This facet analyzes concerns, fears, and concerns about approximation to death. It is believed that this result is due to average age, which was close to 70 years, a period in which individuals understand they have a significant portion of years of life remaining, and partly because there they are not concerned with this fact. In RA, the lowest score found was in sensory abilities, a facet that analyzes sensory capacity and the impact of the loss of sensory abilities. Despite improved access to health services, the elderly require a wide network of care, something which has not yet been satisfactorily established in RA, and the absence of which can lead to greater impairment in this aspect, due to the lack of, for example, specialized care ${ }^{29}$.

In Palmas, Paraná, the location of this study, the situation described by these authors is confirmed. Although there are Family Health teams that cover rural communities, it was noted that elderly residents of these areas have difficulties accessing specific services when affected by an illness, unlike in urban areas. This factor was also highlighted by the aforementioned authors, who point out that there is still a great discrepancy between the access to health services of elderly people residing in UA and RA.

In urban areas, the factor with the lowest score was social participation, which analyzes the possibilities of participation in daily activities, mainly in the community, of the elderly. In a study of the contribution of physical, psychological, social and environmental domains to quality of life of 211 elderly people from the southeast of Brazil, it was demonstrated that the environment in which the elderly live directly influences $\mathrm{QOL}^{28}$. Thus, in unsafe environments, such as urban centers, where there are increasing levels of violence, the elderly are unlikely to go out alone. Research into the perception of QoL of the elderly showed that the reduction of social participation increases the possibility of isolation and susceptibility to health problems and diminishes perception of quality of life ${ }^{30}$, which may have caused this response in the studied group, as a significant number of elderly individuals were alone in their homes during the interviews. 
Another important result of this study was that the urban elderly persons have better economic conditions than rural individuals (Upper Mean Income $=16.2 \%$ and $0.70 \%$, respectively), despite the overall average income being low $88.1 \%$ of the total). Another study by Martins et al. ${ }^{27}$ evaluated the subjective quality of life of 284 elderly people, 125 of whom were residents of 11 rural municipal regions in the state of Paraíba and 159 of whom lived in the capital, João Pessoa. For these authors, a lower income meant a greater propensity of having a negative perception of QoL, while an increase in income was associated with higher QoL scores. In the evaluated group, financial status was considered the main interference factor for the perception of QoL. However, the number of low-income rural subjects in the present study did not allow us to make comparisons with urban individuals based on this variable.

A study on access to and the use of health services by rural elderly people, based on IBGE data, concluded that in UA there is greater ease of access to health services and higher incomes, which facilitates a positive view of quality of life $^{31}$. Another related factor refers to income, which is generally higher in urban environments, allowing the acquisition of consumer goods and the practice of sports and leisure activities, positively affecting QoL ${ }^{32}$. Other evidence found in this study was that there is a greater proportion of active elderly persons in RA (66.91\%), while in UA there are more older individuals who are insufficiently active or sedentary (51.67\%). Araújo et al. ${ }^{20}$ emphasized that even with the onset of old age, the elderly maintain a certain link with previous activities, which allows greater ease of accomplishment of daily tasks and a better perception of QoL. In the urban environment, situations in which the subject continues to carry out the same activities are rare, as there is a great change in daily life upon retirement. Due to the characteristics of the population of the present study, the effective participation of rural elderly persons in the extraction of timber and agricultural activities was identified, and it is believed that this may partly explain the higher indices of physical activity found, which positively affect levels of independence and health. Level of PA has been described as fundamental to maintaining autonomy, independence and functional capacity, as well as in the delay or reversal of ongoing pathological processes, and may also provide psychological benefits such as improved self-esteem, creativity and healthy and active aging. The greater the difficulties in independently performing tasks of daily life, the worse the conception of quality of life $\mathrm{fe}^{33,34}$.

Another relevant finding was that, when analyzing the overall mean scores of the Whoqol-Bref, being active in the UA seems to influence the perception of QoL to a greater extent, while being insufficiently active is unfavorable to the individuals' opinion of their QoL. Being active in both RA and UA resulted in a similar perception of QoL. However, when analyzed with the Whoqol-Old, active and IA elderly persons from RA had significantly higher scores than those from UA. A study of QoL and self-concept in aging in relation to physical activity found a significant association between the level of PA and the quality of life of the elderly $y^{35}$. While there are studies that relate QoL to levels of physical activity, we did not find any work in literature that made such a comparison between rural and urban elderly persons.

The fact that IA subjects present lower scores than active individuals may be related to the fact that those who are insufficiently active or sedentary who are in the transition period between a physically active level and a decrease in such level may feel the effects of the loss of capacity more, while sedentary individuals have already come to accept this situation and may be adapted to other types of tasks, where $\mathrm{PA}$ is not considered of primary importance to QoL.

It was noted that in the present study, especially in RA, that although elderly individuals lose part of their labor capacity for more intense activities in the field, they tend to continue in these tasks and remain active, which may have influenced the results. In UA, the change in the characteristics of PA affects QoL, as active and IA elderly persons perceived their QoL differently. This factor may be associated with the fact that sedentarism has been associated with low levels of autonomy, which interferes with the social participation of the elderly and significantly affects positive or negative perceptions of life, depending on the context in which the subject is inserted. It is believed that, upon retirement, especially in UA, a greater rupture occurs in the daily performance of activities, which 
may impact on social insertion, directly affecting the perception of QoL. It is important to note that the active elderly, irrespective of their environment, had higher scores than those who were insufficiently active or sedentary, even though in some cases there was no statistically significant difference, indicating that the maintenance of an active life positively affects perception of quality of life, regardless of place of residence.

Due to the transversal character of the present study, it was not possible to explain the variability of factors that may affect perception of quality of life, which represents a limitation of this study and, at the same time, a possibility for continuity and the longitudinal follow-up of these individuals, as evaluation of the same human being may provide temporal variations.

More studies are needed to elucidate the causes of high rates of physical inactivity among the elderly, in order to plan actions to encourage a more active life. In spite of the previously mentioned potential limitations of the present study, analysis of the data

\section{REFERENCES}

1. World Health Organization. World report on ageing and health [Internet]. Geneva: WHO; 2015 [acesso em 15 out. 2015.]. Disponível em: http://apps.who. int/iris/bitstream/10665/186463/1/9789240694811_ eng.pdf?ua $=1$

2. Saito T, Sugisawa H, Harada K, Kai I. Population aging in local areas and subjective well-being of older adults: findings from two studies in Japan. Biosci Trends. 2016;10(2):103-12.

3. Pereira EF, Teixeira CS, Santos A. Qualidade de vida: abordagens, conceitos e avaliação. Rev Bras Educ Fís Esporte. 2012;26(2):241-50.

4. Gonzalo Silvestre T, Ubillos Landa S. Women, physical activity, and quality of life: self-concept as a mediator. Span J Psychol. 2016;19(E6):1-9.

5. Vicente FR, Santos SMA. Avaliação multidimensional dos determinantes do envelhecimento ativo em idosos de um município de Santa Catarina. Texto Contexto Enferm. 2013;22(2):370-8. showed that living in rural areas and remaining active is a factor that interferes positively in the perception of QoL of the elderly.

\section{CONCLUSION}

Older residents of RA have better quality of life scores in most Whoqol-Bref and Whoqol-Old domains and are more physically active than their UA-resident peers. It is understood that this result is associated with the way in which social arrangements are organized in rural and urban environments and the fact that work activities in RA are maintained for a longer period of time than in the urban space.

In conclusion, there are important differences between the QoL of the elderly living in rural and urban environments, and levels of physical activity, both in rural and urban areas, are associated with higher QoL scores. Thus, it is important to emphasize the importance of maintaining an active lifestyle, regardless of place of residence, to maintain and/ or improve quality of life.

6. De Mera CMP, Netto CGAM. Envelhecimento dos produtores no meio rural na região do Alto Jacuí/ RS e consequente migração para cidade. Estud Interdiscip Envelhec. 2014;19(3):759-74.

7. Instituto Brasileiro de Geografia e Estatística, Diretoria de Pesquisas. Coordenação de População e Indicadores Sociais. Estudos e Pesquisas. Informação Demográfica e Socioeconômica. Estudo comparativo da independência funcional e qualidade [Internet]. Rio de Janeiro: IBGE; 2010 [acesso em 20 mar. 2013]. Disponível em: http://www.ibge.gov.br/

8. Trindade J. Perfil da atividade física habitual de idosos residentes na zona urbana e rural do município de São Jerônimo da Serra - PR [Monografia]. Universidade Estadual de Londrina, Centro de Educação Física e Esporte. Londrina: UEL; 2012.

9. Lima IF, Azevedo RCS, Reiners AAO, Silva AMC, Souza LC, Almeida NA. Fatores associados à independência funcional de mulheres idosas no município de Cuiabá/MT. Rev Bras Geriatr Gerontol. 2016;19(5):827-37. 
10. Perez AJ, Fiorin A, Robers DS, Tavares O, Farinatti PTV. Estudo comparativo da autonomia de ação de idosas residentes em áreas rurais e urbanas. Rev Bras Cineantropom Desempenho Hum. 2012;14(1):11-22.

11. Tavares DMS, Santos LL, Dias FA, Ferreira PCS, Oliveira EA. Qualidade de vida de idosos rurais e fatores associados. Rev Enferm UFPE on line. 2015; 9(11):9679-87.

12. Ribeiro CG. Qualidade de vida em função do nível da prática de atividades físicas de idosos residentes em meio urbano e rural do município de Palmas/PR [Dissertação]. Chapecó: Universidade Comunitária da Região de Chapecó; 2014.

13. Ferretti F, Beskow GCT, Slaviero RC, Ribeiro CG. Análise da qualidade de vida em idosos praticantes e não praticantes de exercício físico regular. Estud Interdiscip Envelhec. 2015;20(3):729-43.

14. Silva EF, Paniz VMV, Laste G, Torres ILS. Prevalência de morbidades e sintomas em idosos: um estudo comparativo entre zonas rural e urbana. Ciênc Saúde Coletiva. 2013;18(4):1029-40.

15. Melo DM, Barbosa AJG. O uso do Mini-Exame do Estado Mental em pesquisas com idosos no Brasil: uma revisão sistemática. Ciênc Saúde Coletiva. 2015;20(12):3865-76.

16. Fleck MPA, Louzada S, Xavier M, Chachamovich E, Vieira G, Santos L, et al. Aplicação da versão em português do Instrumento de avaliação de qualidade de vida da OMS (WHOQOL-100). Rev Saúde Pública. 1999;33(2):198-205.

17. Chachamovic E. Qualidade de vida em idosos: desenvolvimento e aplicação do módulo Whoqol-Old e teste de desempenho do instrumento Whoqol-Bref em uma amostra de idosos brasileiros [Dissertação]. Porto Alegre: Universidade Federal do Rio Grande do Sul; 2005.

18. Rinaldo ML, Passos PCB, Rocha FF, Milani JL, Vieira LF. Qualidade de vida e atividade física: um estudo correlacional em idosos com hipertensão arterial sistêmica. Arq Ciênc Saúde. 2016;20(1):51-7.

19. Associação Brasileira de Empresas de Pesquisa. Critérios de Classificação Econômica Brasil [Internet]. São Paulo: ABEP; 2013 [acesso em 12 maio 2013]. Disponível em: www.abep.org

20. Araújo SA, Fontes BC, Carvalho MDS, Nascimento JMMF. Gênero, geração e trabalho: modos de vida de idosos/as residentes em zona rural. Rev Bras Ciênc Envelhec Hum. 2013;10(1):66-78.
21. Cabral SOL, Oliveira CCC, Vargas MM, Neves ACS. Condições de ambiente e saúde em idosos residentes nas zonas rural e urbana em um município da região Nordeste. Geriatr Gerontol. 2010;4(2):76-84.

22. Fonseca AM, Paúl C, Martin I, Amado J. Condição psicossocial de idosos rurais numa aldeia do interior de Portugal. In: Paúl M, AM Fonseca, coordenadores. Envelhecer em Portugal: psicologia, saúde e prestação de cuidados. Lisboa: Climepsi, 2005. p. 97-108.

23. Teixeira LMF. Solidão, depressão e qualidade de vida em idosos: um estudo avaliativo exploratório e implementação-piloto de um programa de intervenção [Dissertação]. Lisboa: Universidade de Lisboa; 2010.

24. Simonetti MCL. Assentamentos rurais e cidadania: a construção de novos espaços de vida. Marília: Cultura Acadêmica - Oficina Universitária; 2011.

25. Tavares DMS, Gomes NC, Dias FA, Santos NMF. Fatores associados à qualidade de vida de idosos com osteoporose residentes na zona rural. Esc Anna Nery Enferm. 2012;16(2):371-8.

26. Tavares DMS, Fachinelli AMP, Dias FA, Bolina AF, Paiva MM. Preditores da qualidade de vida de idosos urbanos e rurais. Rev Baiana Enferm. 2015;29(4):361-71.

27. Martins CR, Albuquerque JFB, Gouveia CNNA, Rodrigues CFF, Neves MTS. Avaliação da qualidade de vida subjetiva dos idosos: uma comparação entre os residentes em cidades rurais e urbanas. Estud Interdiscip Envelhec. 2007;11:135-54.

28. Pereira RJ, Cotta RMM, Franceschini SCC, Ribeiro RCL, Sampaio RF, Priore SE, et al. Contribuição dos domínios físico, social, psicológico e ambiental para a qualidade de vida global de idosos. Rev Psiquiatr. 2006;28(1):27-38.

29. Rodrigues LR, Silva ATM, Dias FA, Ferreira PCS, Silva LMA, Viana DA, et al. Perfil sociodemográfico, econômico e de saúde de idosos rurais segundo o indicativo de depressão. Rev Eletrônica Enferm. 2014;16(2):278-85.

30. Dias DSG, Carvalho CS, Araújo CV. Comparação da percepção subjetiva de qualidade de vida e bemestar de idosos que vivem sozinhos com a família e institucionalizados. Rev Bras Geriatr Gerontol. 2013;16(1):127-38.

31. Rodrigues LR, Silva ATM, Dias FA, Ferreira PCS, Silva LMA, Viana DA, et al. Perfil sociodemográfico, econômico e de saúde de idosos rurais segundo o indicativo de depressão. Rev Eletrônica Enferm [Internet]. 2014 [acesso em 15 out. 2015.];16(2):278-85. 
32. Sequeira A, Silva MN. O bem-estar da pessoa idosa em meio rural. Anál Psicol. 2002;20(3):505-16.

33. Ferreira OGL, Maciel SC, Costa SMG, Silva AO, Moreira MASP. Envelhecimento ativo e sua relação com a independência funcional. Texto Contexto Enferm 2012;21(3):513-8.

Received: June 21, 2016

Reviewed: January 16, 2017

Accepted: April 24, 2017
34. Gomes Neto M, Castro MF. Estudo comparativo da independência funcional e qualidade de vida entre idosos ativos e sedentários. Rev Bras Med Esporte 2012;18(4):234-7.

35. Rolim FS. Atividade física e os domínios da qualidade de vida e do autoconceito no processo de envelhecimento [Dissertação]. Campinas: Universidade Estadual de Campinas, Faculdade de Educação Física; 2005. 